\title{
Ofis Tasarımında Ergonomik ve Antropometrik Etkenler
}

\author{
Bilge YARAREL ${ }^{1 *}$
}

Öz

Ergonomi, insan ve bulunduğu çevrenin fiziksel ve psikolojik açıdan birbirleri ile uyumlandırılması, insanın bedensel ve ruhsal yönden zorlamadan yeteneklerini en rahat şekilde kullanabilme süreci olarak tanımlanmaktadır. İnsanlar ve makineler üzerinde çeşitli iş ve çevre koşullarına ilişkin özellikler, eğilimler, yetenekler ve sınırlılıklar bulunmaktadır. Günümüz modern dünyasında ofis çalışanlarının çoğu çalışma ortamları ve koşulları açısından çeşitli problemlerle karşılaşmakta ve bu durum çalışanların beden ve ruh sağlığı ile iş verimliliklerini olumsuz yönde etkilemektedir.

İş yerlerinde meydana gelen sorunlar, araç-gereçlerin ve mobilyaların ergonomik etkenler göz önüne alınmadan tasarlanması, uygun olmayan çevresel koşullar ve insanın bir makine gibi düşünülmesi, psikolojik olarak çalışanlar üzerinden incelendiğinde huzursuzluğa, tatminsizliğe ve iş veriminde düşüşe neden olmaktadır. Bu durum çalışanların psikolojisini olumsuz yönde etkilemektedir. İnsanın psikolojik ve fizyolojik yönden olumsuz etkilenmesinin önüne geçilmesi, onun gelişen teknoloji, makineler ve çalışma sistemleri karşısında yetersiz kalmasını önleyecek ofis mekanlarının düzenlenmesiyle sağlanabilir. İnsanın antropometrik ölçüleri, anatomik yapısı, fizyolojik kapasitesi ve toleransları göz önünde tutulmalıdır. Endüstriyel iş ortamında oluşabilecek, organik ve psikolojik stresler karşısında minimum değerde etkilenmeyi sağlayacak ergonomik ve antropometrik veriler doğrultusunda araştırmalar yapılmalıdır. Bu çalışmanın amacı, ofis ergonomisinin çalışma psikolojisine ve iş verimine etkisini incelemektir. Bu çalışmada, literatür taraması yapılarak bu konuda yayınlanmış makaleler ve diğer bilimsel kaynaklardan yararlanılmıştır.

Anahtar Kelimeler: Ergonomi, Antropometri, Ofis, Çalışan Sağlığı, Çevresel Etkenler

\section{Ergonomic and Antropometric Effects in Office Design}

\begin{abstract}
Absract
Ergonomy is defined as the orientation process of people and the environment in terms of physical and psychological aspects, the process of people use their potentials without any bodily or mental difficulties. There are features regarding various professions and environmental conditions as well as tendencies, abilities and limitations on people and machines. In today's contemporary world, most of the office workers face with some problems about working environments and conditions that affects the bodily and mental health as well as labor productivity the employees negatively.
\end{abstract}

\footnotetext{
${ }^{1}$ Dr. Öğr. Üyesi., İstinye Üniversitesi, Güzel Sanatlar, Tasarım ve Mimarlık Fakültesi, İç Mimarlık ve Çevre Tasarımı Bölümü

*ilgili Yazar/ Corresponding Author: Bilge YARAREL, bilgeyararel@gmail.com, 05321741688

Gönderim Tarihi: 19.04.2019

Kabul Tarihi: 29.06.2019
} 
The problems which emerge in the work place, designing the tools and furnitures without considering the ergonomic factors, unsuitable environmental conditions and considering people as machines led uneasiness, dissatisfaction and reduced labor productivity among people. Dicrease in labor productivity affect employees'psychology negatively. In order to prevent this psychological and physical negativity, the arrangement of the office spaces in a way that doesn't let people fail before machines and working systems is necessary. By considering human antropometric measurament, anatomic structure, physiological capacity and tolerance; by providing the conditions which make them get affected under organic and psychological stress minimal, new thought systems and newfuture thought systems must be build by researching ergonomic office designs. The scope of this work is examining the office furniture's effect on working psychology and labor productivity. In this work, the articles and other scientific resources are used by making a literatüre review.

Keywords: Ergonomy, Antropometri, Office, Worker Health, Environment Effects

\section{GíRiş}

Günümüz insanı, zamanının büyük bir bölümünü geçirdiği çalışma alanı olan ofisler ile sürekli olarak hem sosyal hem de mekansal etkileşim halindedir. Bu etkileşim mekansal bağlamda incelendiğinde ergonominin öneminin yadsınamayacak kadar büyük olduğu görülmektedir. İnsan ve çevresinin uyumlandırılması olarak tanımlanan ergonomi, çalışanların işe motive olmasında ve iş veriminin artmasında önemli bir araçtır. Ergonomi bilimi, çalışanın daha rahat bir ortamda çalışmasını öngörür. Çeşitli kurum ya da kuruluşların hizmet alanları kapsamında gerçekleştirilen faaliyetlerin yürütüldüğü mekanlar olan ofislerde; fiziksel ortamların düzeni, çalışan sağlığına, psikolojisine ve iş verimine olan etkisinden dolayı oldukça önemlidir. Ofis içinde yapılan çalışmaların verimli ve kaliteli olmasında en önemli faktörlerden biri de fiziki çevredir. Ofis çalışanları ve kullanıcıları zamanlarının büyük bir kısmını bu mekanlar içerisinde geçirmektedir. Dolayısıyla ofislerin, kullanıcıların rahat edeceği bir şekilde ergonomik unsurlarla birlikte tasarlanması gerekir. İnsan-makine-çevre üçlüsünün birbirleri ile olan ilişkisindeki en önemli faktörün insan olduğu unutulmamalıdır. Çalışma alanının, bu alanda kullanılan makinaların ve insanın çalışmasına etki edebilecek yakın çevrenin incelenerek antropometrik ölçülere uygun biçimde düzenlenmesi gerekmektedir. Uygun düzenleme insanın dış etkilere karşı verebileceği tepkiler, çevresi ile olan olumlu ve olumsuz etkileşimleriyle birlikte psikolojisi de göz önünde bulundurularak yapıldığında iş verimliliği üzerinde etkili olmaktadır.

$\mathrm{Bu}$ çalışmada, ofis mekanları ve mobilyası tasarımında ergonomik ve antropometrik yaklaşımın önemi irdelenmiştir. Ayrıca ofis ve ofis mekan tasarımında ergonomik analizlerin önemi ortaya konmuştur. Çalışma sonunda ergonomik ofis tasarımına ilişkin öneriler sıralanmıştır.

\section{ERGONOMI}

İnsan hayatında önemli bir yer tutan ergonomi çok geniş bir alana yayılmıştır. Ergonomik ve antropometrik verilerle insanın kullanımına yönelik ürün tasarımında, özellikle çalışma ve ofis hayatında uzun saatler kullanılan mobilyaların insanın fizyolojik sınırları göz önünde tutularak düşünülmesi ve üretilmesi oldukça önem taşımaktadır. "Ergonomi" kelimesi eski Yunanca iş anlamına gelen "Ergo" ve doğal düzen anlamına gelen "Nomos" kelimelerinden üretilmiştir. 
Ergonomi, insan-makine etkileşimini, insanın çeşitli iş ve çevre koşullarına ilişkin bedensel ve ruhsal özelliklerini, eğilim ve yeteneklerini, sınırılıklarını araştıran, elde ettiği veriler sayesinde makine ve makine sistemlerinin, iş ve çevre koşullarının düzenlenmesini sağlayan bilim dalıdır (Kıraç, 2005,s:7). İnsanın iş yükünün ve çalışma gücünün olabilecek en uygun şekilde düşünülmesi" temeline dayanan ergonomi; "İnsan - makine - çevre sisteminin başarılı bir şekilde çalışması ve üretimin artması için biyolojik bilginin anatomi, fizyoloji ve deneysel psikoloji alanlarında uygulanmasıdır (Güler, 1997).

Antropometrik ölçüler; yaş, kilo, boy, cinsiyet, beslenme ve insanın yaşadığı bölgeye göre farklılık göstermektedir. İnsanların vücut ölçülerine uygun tasarlanan mobilyalar, kişilerin mobilyayı rahat ve tam verim alarak kullanabilmesini sağlar. Üretilen ya da tasarlanma aşamasında olan mobilyalar kullanıcının (bebek, çocuk, genç, yetişkin, yaşlı, engelli vb.) bedensel, ruhsal özelliklerine ve antropometrik ölçümlerine uygun tasarlanmalıdır. Antropometrik ölçütlere uygun olmayan mobilyalar kullanıcıların yapısal ve fiziksel gelişimlerini olumsuz yönde etkilemektedir" (Kurban, Kaygın, Tankut, s:314).

Ergonomi makineli bir üretim sisteminde çalışan insanın bedensel sağlığını korumak ve onun güvenliğini sağlamayı, ortaya çıkan işin nicelik ve niteliğini artırmayı hedefler. 18. yy'ın ikinci yarısında F.W Taylor'ın çalışanlardan nasıl daha çok verim sağlanabilir ve aynı zamanda bedensel sağlıkları da korunabilir sorusu üzerine çeşitli düşünceler geliştirmesiyle ivme kazanmıştır. İnsan Ölçüleri ve makineleşmenin insana uyarlanması konusunda yapılan çalışmaların farklı disiplinlerden ("Anatomi”, "Antropoloji”, "Fizyoloji”, "Psikoloji", "Mühendislik Bilimleri" ve "Tasarım" gibi) oluşarak bir araya gelmesiyle, bir bilim dalı olarak "Ergonomi" tek bir ana başlık altında toplanmıştır (Kıraç, 2005)

Çalışanların yaptıkları iş, vücut ölçüleri, çalışma sırasında kullandıkları alanlar birbirinden farklıdır, aynı olması beklenemez. Pek çok farklı özelliğe sahip insanın bir arada çalıştığı ofislerde ergonomi bilimi diğer disiplinlerden faydalanır.

Ergonomi alanındaki çalışmalar sonucunda hedeflenen noktalar genel olarak şunlardır:

- - İş̧i sağlığı ve iş güvenliğinin sağlanması

- -İşücü kayıplarının önlenmesi

- -Yorulmanın ve iş stresinin azaltılması

- - İş kazaları ve mesleki risklerin minimizasyonu

- -Verimlilik ve kalitenin yükseltilmesi (Su, 2001).

Ergonomi üzerinde etkili olan faktörler aşağıdaki şekliyle sıralanabilir;

\subsection{Psikolojik Unsurlar}

İnsan davranışlarını ve süreçlerini inceleyen bir bilim dalı olan psikoloji algı, uyumluluk ve iş öğrenimi gibi konularla ergonomiye yarar sağlamaktadır. Çalışma ortamında renk, şekil, düzen gibi psikolojik yönden rahatlık sağlayıcı düzenlemeler yoluyla çalışana uygun bir ortam oluşturulmasını amaçlamaktadır. Ayrıca algı, odaklanma ve iş öğrenimi gibi konularla birlikte deneysel psikoloji çalışmalarıyla ergonomiye katkı sağlamaktadır. Ergonomi psikolojiden bazı yöntemleri alır ve kullanır. Sonuç olarak psikoloji ile ergonomi arasındaki ilişkilerin çok derin ve önemli olduğu yargısına varmak mümkündür (Kıraç, 2005). 


\subsection{Fizyolojik Unsurlar}

Canlıların mekanik, fiziksel, biyokimyasal işlevlerini ve sistemlerinin işleyişini inceleyen bilim olan fizyoloji, çalışma ortamı ve çalışma yöntemlerinin insan bünyesi ve insan bünyesine elverişli çevre şartları konularında ergonomiye yarar sağlamaktadır.

"Kas çalışması dinamik ve statik çalışma, enerji harcamasının değerlenmesi, ısı ve ısıya karşı tepki gibi konularda yaptığı incelemelerle fizyoloji, ergonomik çalışmalara ışık tutmaktadır" (Kıraç, 2005).

Uygun ve doğru olmayan vücut duruş ve hareketlerinin tekrarlanması sonucu kas iskelet sistemi rahatsızlıklarının ortaya çıkması hem çalışan, hem işveren açısından iş veriminde kayıpların ve yetersizliklerin yaşanmasına neden olmaktadır. Bu durum uzun süreli çalışmalar gerektiren ofis ortamında ve ofis mobilyalarının kullanımında daha etkili biçimde ortaya çıkmaktadır.

\subsection{Sosyolojik Unsurlar}

Toplum ve insanın etkileşimi üzerine çalışan bir bilim olan sosyoloji alanında yapılan çalışmalar ergonomiye katkıda bulunmaktadır. Ergonominin sosyolojik çalışmalardan yararlandığı ve sonucunda bazı toplumsal sorunları çözdüğü öne sürülebilir

Ergonomi alanında çalışmalar yapan "ergonomlar", insan çalışmasını en verimli hale getirebilmek için yöntemler geliştiren "iş etütçüler" ile beraber çalışmaktadırlar. Bu yapılan çalışmalara iş bilim çerçevesinde bakıldığında, insanın kendini işe uydurma oranının \%85 iken, işin insana uydurulma oranının \%15 olduğu görülmüştür. İnsanın işe uyumlandırılması için çeşitli eğitim ve alıştırma yolları bulunmaktadır (Kıraç, 2005). İşin insana uydurulmasında ise insanın antropometrik ölçülerinin ve ihtiyaçlarının bilinmesi gerekmektedir. Ancak bu şekilde verimliliğin artmasına yönelik performans ölçümleri yapılabilmektedir. İnsan performansı için diğer bir önemli bir diğer faktör de "motivasyon" dur. Bu motivasyonun sağlanabilmesi işin gerekleri ve insanın yeteneklerinin birbirleriyle uyuşması ile oluşturulabilir. Unutulmamalıdır ki; insan çalışırken çevresel faktörlerin etkisi altında bulunmaktadır. Çalışma ortamında işveren ve iş gören bakımından çeşitli memnuniyetsizlikler ortaya çıkabilir. İşte bu noktada birebir uyuşmanın sağlanmasının gerekliği anlaşılmaktadır.

\section{ANTROPOMETRININ TANIMI}

Antropometri bilimi, yaptığı araştırmalar ve insan ölçümlerinden elde ettiği antropometrik veriler doğrultusunda farklı iş alanlarındaki araç-gereçlerin fiziksel ölçülerini belirlemek için kullanılmaktadır. Böylelikle alet, araç gereçlerin ve ürünlerin ölçüleri ile onları kullanan insanların ölçülerini birbirine uyumlu hale getirilerek yapılacak işi kullanıcıya yani insana uyumlu hale dönüştürmektedir. Ergonomik tasarımda hangi ürün olursa olsun dikkate alınması gereken önemli kriterlerden biri ürünü kullanacak olanın antropometrik boyutlarıdır. Ürünü kullanacak veya ondan yararlanacak olanın antropometrik ölçüleri dikkate alınmadan üretilecek ürünün işlevselliğinden, yararlı olmasından söz etmek mümkün değildir.

Antropometrik ölçüler ürünün bir noktada kalıbını oluşturmaktadır. Yaşam koşullarının uygun hale getirilmesinde ve standartların yükseltilmesinde, makine, yapı, giysi, alet ve donanım başta olmak üzere her türlü ürünün tasarım aşamasından başlayarak üretim ve kullanım aşamalarında o ürünü kullanacak veya ondan yararlanacak olanın insan 
olduğu göz önünde tutularak, ürünün amaca uygunluğu kesin olarak sağlanmak zorundadır.

Ürünler insan, makine ve çevre ilişkisine göre tasarlanıp üretilmelidir. Bu uyum ve ilişkinin sağlanmasında insanın özellik ve kapasitelerinin tespiti çok önemlidir. Bu özellik ve kapasitelerin tespiti için antropometri yaygın olarak kullanılan tekniklerden biridir. Antropometrik değerler sağlık, ergonomi, spor, mühendislik, giysi tasarımı, mimarlık ve endüstriyel tasarım alanlarında yapılan her türlü çalışma ve tasarımda maksimum fayda sağlamaktadır.

18. yüzyılın sonlarında insan vücut ölçülerinin incelenmesine başlanmıştır. İncelemelerde daha çok tıbbi kayıtlar elde etme, ticari ürünler gibi belli alanlarda tasarımlar yapma üzerine veriler toplanmıştır. Yapılan çalışma vücut ölçülerinin ve yapısının araç-gereç tasarımına olan etkilerine yönelik ilerlemiş ve tıp, fizyoloji, psikoloji ve antropoloji alanlarının mühendislikle birleşmesine ve ergonomi biliminin doğmasına yol açmıştır. 1912 yılında antropometri mühendisliği dalında ilk uygulamaya yönelik bilimsel çalışma Gilberth lerin iş verimini arttırmak amacıyla yaptıkları "hareket etüdü"dür. Yapılan bu etüt çalışmaları ile gerçekleştirilecek iş için kullanılacak araç gerecin, işgörenin kolayca ulaşabileceği bir yerde bulundurulmasının önemi anlaşılmış, sonuç olarak da iş yeri ve atölyelerin bilimsel olarak tasarımı yapılmaya başlanmıştır (Kahraman, 2013).

Antropometri insan vücudunun fiziksel özelliklerini ölçme esasları ile boyutlandıran sistematik tekniklere dayalı bir bilim dalıdır. Antropometride ölçümler statik ve dinamik olmak üzere iki durumda yapılır. Statik veriler boy, uzunluk, çevre ve deri kalınlığı gibi ölçümlerdir. Bu ölçümler, birey anatomik pozisyonda veya sabit durumda iken yapılmaktadır. Anatomik pozisyon; ayakta dik duran, topukları ve ayak başparmakları birleşmiş, el ayaları öne, yüzü karşıya bakacak şekilde duran bir insanın duruşudur. Dinamik veriler; eğilme, uzanma ve dönme hareketlerinin sınırlarının ölçülmesi sonucu elde edilmektedir. Statik ve dinamik ölçümler için mezure, Antropometre, kayan kaliper deri kıvrımı ölçüm aleti, gonyometre, inklinometre gibi araçlar ve üç boyutlu dijital yöntemler kullanılmaktadır (Durgun, 2010; Oborne, 1995).

Antropometrik değerler sağlıklı bir şekilde elde edilip öngörülen yüzdelik değerlerine göre belirlendiğinde o sistemde çalışan insanın yüklenme ve dolayısıyla zorlanma faktörlerini de olumlu şekilde etkilemek mümkündür. İnsanın konfor sınırları içindeki tüm diğer ergonomik faktörler yanında verimlilik ve üretkenlik değerleri de göz önüne alınarak, standart sapmalarına göre genellikle $\% 90$ ve $\% 95$ güvenlik sınırları içinde üst ve alt antropometrik değerler veya ayarlama aralıkları belirlenebilir. Antropometrik veriler ele alınırken, kullanıcıya uyumu açısından doğru verilerin toplanması için doğru kullanıcı nüfusu incelenmelidir. Bu incelemede grubun ortalama vücut boyutları yetersiz olacağından standart sapmada tahmin edilmek zorundadır. Grup içerisindeki insanların bir kısmı ortalamaya yakın bir kısmı uzak bir kısmı da tamamen farklı olacağından kullanıcıların bazıları feda edilmek zorunda kalınacaktır. Bu durumu en aza indirgemek için antropometrik araştırmalarda, kullanıcı grubun çeşitliliği göz önüne alınmalıdır. Ayrıca bireylerin gereksinimlerini karşılayacak tasarımların, mekanların, sistemlerin, ürünlerin vb. yapılabilmesi için vücudun farklı ölçüleri ölçüm kapsamında olmalıdır (Özok, Kaya, 2017). 


\section{OFIS TANIMI}

Ofis ve büro kelime anlamı olarak literatürde eş anlamlı olarak kullanılmaktadır. Etimolojilerine bakıldığında farklı köklerden geldikleri anlaşımaktadır.

Büro kavramının mimari sözlükteki tanımı; yazı ve yönetim işlerinin çalışma alanları, bunların gereksinimlerini karşılayacak hacimleri barındıran binalardır. Ofis ise sayısız belgenin, hesabın ve görsel malzemenin toplandığı, depolandığı, iletildiği ve dağıtıldığı, bilgiye dayalı işlerin özelleştirilmiş mekanıdır.

Ofisler, genel olarak içinde yapılacak işin mahiyetine göre gerekli demirbaş ve diğer yardımcı vasıtalarla donatılmışlardır. Bilgi ve iletişim teknolojilerindeki hızlı ilerlemenin sonucunda, yapısı ve işleyişi önemli ölçüde değişmiş günümüz ofis oluşumları görülmektedir. Ofislerin mekansal örgütlenme tipolojisi incelendiğinde üç tip oluşum görülmektedir. Tarihsel süreç içinde ilk karşılaşılan ofis tipi "Kapalı Düzen" ofis mekanlarıdır. Mekan düzenlemesi; kişilerin bir koridor etrafında bulunan irili ufaklı mekanlara, alan standartları ve bina modülleri esas alınarak yerleştirilmesidir (Harris, 1991).

Serbest düzen ofis mekanı anlayışı ise, 1960'da Almanya'nın Quickborn şehrinde, Schnelle kardeşlerin geliştirdiği bir sistemdir. Mekan düzenlemesi; çekirdekten çalışma mekanlarına uzanan ana ulaşım yollarının etrafı, değişebilen elemanlarla sınırlanmıştır Karma düzen ofisler 80 'li yıllarda ortaya çıkmıştır. Hücresel, serbest ve grup düzeninde ofis tipinin bir arada kullanıldığı bir oluşumdur. Açık ofis düzenlemesinde zaman içinde çalışan personelin şikayetleri üzerine, mekan içinde yeterli işitsel konforun ve kişisel mahremiyetin sağlanamaması konularının iyileştirilmesi üzerine yoğunlaşımış ve karma ofis düzeni ortaya çıkmıştır (Güler, 1997).

Karma ofis düzeninin ortaya çıkması hem kapalı ofis düzenindeki haberleşme kavramını kısıtlayan kapalı mekan yerleşimini, hem de açık ofis düzenindeki mahremiyet yetersizliğini ortadan kaldırmıştır.

\section{ERGONOMIK ve ANTROPOMETRIK OFIS TASARIMINA ETKI EDEN FAKTÖRLER}

Gelişen teknoloji ve farklılaşan iş kollarıyla birlikte işlerin yapılma biçimi de değişmiştir. Bugüne kadar elle ve somut öğelerle yapılan işler artık bilgilerin dijital ortamlarda işlenmesi şekline bürünmüştür. Yeni ofis oluşumlarının sonucu olarak, ofis tasarımlarında farklılaşmalar ve yeni çözüm teknikleri geliştirilmiştir. Verimliliğe önem veren işletmeler, ofislerde teknolojik araç ve gereçleri yeniden düzenlemekte, çalışanlar da bu yeni sistemlere kendilerini alıştırmaktadırlar. Kapalı tip ofislerde bir ya da birkaç kişi çalışırken, bugün yüzlerce kişiyi tek bir alanda toplayan açık ofis kullanımı oldukça yaygındır. Bu ofislerde çalışanın motivasyonunun sağlanması ve gerekli aydınlatma ve ısı düzeyi gibi sorunların tek bir kişiye göre değil fazla sayıda kişiye göre ayarlanarak herkesi eşit şekilde memnun etme problemi yaşanabilmektedir. Oluşabilecek diğer bir sorun yerleşim alanlarının kısıtlı olması nedeniyle hareket kabiliyetinin en aza indirgenmesi ve esnekliğin ortadan kalkmasıdır. Bu olumsuzluklarla birlikte çalışma ortamı gittikçe kişisellikten uzaklaşır, gürültü kaçınılmaz olur, bulaşıcı hastalıkların yayılma riski artar. İ̧ akışına uygun olarak düzenlenmesi gereken ofislerde iş verimliliği bakımından bu unsurlar göz önünde bulundurularak çözümler üretilmelidir. 
Çevreye bağlı olarak çalışan üzerinde etkili olan faktörler aşağıdaki gibi sıralanabilir;

- Aydınlatma

- Ses Yalıtımı

- İklimlendirme

- Renk

- Çevresel Faktörler

\subsection{Aydınlatma}

Çalışma ortamlarında iş görenler, yaptıkları işlere, bulundukları ortama ve genel çevrelerine veya iş alanı içindeki çeşitli noktalara bakmak durumundadırlar. Bakma eylemini gerçekleştirirken dikkatlerini en çok parlak ve renkli bölgeler çeker. Bu durumda ortaya çıkan sonuç iş görenin çalıştığı alanın kendisi için en iyi aydınlatılmış alan olmasıdır. Aydınlık düzeyi kullandığı araç-gereçleri ve çalıştığı ortamdaki gerekli detayları algılayabilmesi için yetersiz ise, çalışanın konforlu olduğu düzeyi sağlamak gerekmektedir. Ofis aydınlatmasında iki tip aydınlatma şekli vardır; "Doğal" ve "Yapay" aydınlatma. Gün ışığını alarak oluşturulan doğal aydınlatmada ışık tek taraftan, iki taraftan veya tepeden alınarak sağlanabilir. Yeterli aydınlık seviyesine ulaşabilmek için, ofis yerleşimlerinin bu unsur göz önünde tutularak düzenlenmesi gerekmektedir. Gün ışığının yetersiz kaldığı veya olmadığı durumlarda yapay aydınlatmanın gücünden faydalanmak gerekir (Güler, 1997-38).

"Ofis aydınlatmalarında kullanılan yapay ışık çeşitlerinde "beyaz ışık" veren florasan ve cıvalı ampuller kullanıır. Bu tür bir ışığın sağlanamadığı ortamlarda "kırmızı ışık" veren normal ampullerin kullanııması uygundur. Normal ampul kullanımında ışığın kamufle edilmesi intiyacı ortaya çıkmaktadır. Bu tip bir durumda çalışanla ışık kaynağı arasına ampulün önüne buzlu cam, beyaz mukavva veya kalın beyaz kağıt konarak, ışığın tavana ya da duvara çarparak gözlere yansıması sağlanmalıdır." (Battaloğlu, 1998-68) "Ofislerde çalışma yapılan ortamlar tekdüze aydınlatılır. Bu nedenle lambalar arası uzaklığın, lambanın masadan yüksekliğinin 1.5 katını aşmaması gerekir. Ayrıca ışıklık yerleri, Çalışma masalarının konumuna göre saptanır. Bu duruma, istenmeyen yansımaları gidermek için özen gösterilmelidir" (Su,2001-170).

Son yıllarda yapılan bazı araştırmalar ve denemeler sonucunda ışığın geliş yönünün çalışanın sol omuzunun arkasından gelmesinin daha uygun olacağı ortaya çıkmıştır. Bunun nedeni, baş ve elin gölgesinin çalışan kişinin çalıştığı alanın sağ ilerisine düşmesinin sağlanmasıdır. Böylece çalışması engellenmemiş olacaktır. Yapay aydınlatma ileri bir homojen çalışma koşulları sağlayabilmektedir ve bu durumun çalışan üzerinde oldukça fazla olumlu psikolojik etkileri bulunmaktadır. İnsanın doğası gereği doğal ışığa karşı bir intiyacı bulunmaktadır. Gelişen teknoloji ve üretilen yeni ürünler sayesinde günümüzde ofislerin doğru aydınlatılabilmesi için her türlü araç mevcuttur. Bu araçların doğru ve uygun biçimde bir araya getirilip kullanılarak çalışma alanlarının oluşturulması mümkündür. "Ofis aydınlatmalarında çalışmanın verimli olabilmesi için alınması gereken önlemleri sıralamak aşağıdaki şekilde sıralanabilir.

- Parlamanın Önlenmesi

- Işık Titreşimlerinin Önlenmesi

- Gölge Düşüşünün Önlenmesi

- Renklerin Doğru Algılanabilmesi" (Kıraç, 2005). 


\subsection{Ses Yalıtımı}

Gürültü hem ruh, hem beden sağlığını olumsuz yönde etkileyen ve insan üzerinde stres oluşumuna neden olan bir faktördür. Özellikle çalışma ortamlarında kişinin dikkatinin dağılması ve odaklanmasını engelleyerek iş verimini düşürmektedir. Seslerin 40 Db'den fazla olması durumunda, insanın sağlığını bozan gürültü kirliliği oluşmaktadır. Gürültü; kişinin kendini dinlemesini ve düşüncelerini toparlayarak aktarmasını engellemekle birlikte dalgınlığa yol açabilmektedir. Bu etkenlerin yol açacağı olumsuzlukların önüne geçebilmek için ofis ortamlarında gürültüyü giderici çeşitli önlemler alınmalıdır. Ses yalıtımı için çeşitli örtücü sistemlerle birlikte, açık ofislerde yakın iletişim içinde olmak zorunda kalan iş görenlerin daha rahat çalışabilmeleri için ses yutucu özelliğe sahip bölücü elemanlar kullanılabilir (Güler, 1997-43).

\subsection{Iklimlendirme}

Çalışma ortamlarında ısı seviyeleri çalışma düzeyini etkileyen önemli faktörlerden biridir. İnsanlar, vücut ısılarında oluşabilecek ani değişikliklerden rahatsız olurlar ve zaten bu değişimlere çok dayanıklı değillerdir. Kendilerini rahat hissedebilmeleri için alışık oldukları ve rahat ettikleri ısı seviyesinde çalışmaları gerekmektedir.

Ofislerin iyi havalandırıması gerekmektedir. Temiz hava alımı insanın daha rahat çalışabilmesi ve odaklanabilmesi için oldukça gereklidir. Özellikle fazla sayıda kişinin çalıştığı ofis ortamlarında gerekli hava miktarının sağlanması ve temiz hava akışının düzeninin sağlanması önemlidir.

Vücut sıcaklığının belirli bir seviyede tutulması insan sağığı için önemlidir. Değerlerin aşırı değişimler göstermemesi çalışanın rahatlığını korumasına yardımcı olur. Yükselen ve düşen sıcaklık dereceleri kadar, aşırı nemin veya nemsizliğinde insan sağlığı ve çalışma verimi üzerine etkileri bulunmaktadır. Fazla sıcak ve nemsizlik insanın dayanıklıı̆ının azalmasına ve çeşitli solunum yolu rahatsızlıklarına sebep olarak sağlığının etkilenmesine dolayısıyla da iş verimliliğinin düşmesine sebep olur. Nem oranının düşük olduğu ortamlarda, buhar makineleri, nem seviyesini ayarlama cihazları ve klimalar gibi yardımcı elemanlar yardımıyla nem düzeyi arttırılabilir veya aynı seviyede korunabilir. Sıcaklık ayarlaması içinde yine klimalardan faydalanmak ve temiz hava akışını sağlamak mümkündür (Güler, 1997-56).

\subsection{Renk}

İnsanın ruhsal durumu ve dolayısıyla performansı açısından önemli olan renk, insan üzerinde psişik ve fiziksel etkilerin oluşmasına neden olur.

İnsanlarda renk duygusunun oluşması için bir cisimden yansıyan ışığın yanı sıra, gelen ışık karşısında normal çalışan bir göz ve beyinde kusursuz bir görme merkezi gerekir. Bu bağlamda renk şu üç sistemde incelenir:

- Psikolojik sistemde renk: Beynimizde uyanan bir duyumdur.

- Fizyolojik sistemde renk: Çeşitli ışık cinslerinin göz retinası üstündeki sinirler vasıtasıyla oluşturduğu fizyolojik bir olaylardır. Sinir sistemlerimizde renk mevcuttur.

- Fiziksel sistemde renk: "Işığın hangi dalga uzunluklarını hangi oranda bulundurduğuna dair, ölçülerle rakamlarla ifade edilebilen değerleridir. Göz bu 
dalga titreşimlerini renk sinirleri vasıtasıyla beyne gönderir ve renk görülür (Çağlarca, 1993).

Çevre ile insan arasındaki etkileşim ışık ve renk uyaranlarının oluşturduğu görsel algılamalarımıza dayanmaktadır. Işık frekansının belli bir oranda yoğunlaşması sonucunda oluşan renkler, düşük ya da yüksek titreşimli enerjileriyle insanın psikolojisine ve davranış şekillerine etki edebilmektedir. "Renklerin psikolojik etkileri, insanın zihinsel aktivitelerini, fiziksel performansını, psiko-sosyal durumunu etkilemekte, insan-donanım-çevre sistemi içinde önemli bir rol üstlenmektedir" (Duran Sağocak, 2005).

Renk konusunda yapılan araştırmalardan elde edilen bulgular;

Renklerin insanda uyandırdığı fizyolojik ve psikolojik etkiler göz önüne alındığında hareketlerimizi ve reaksiyonlarımızı etkilediği ortaya konulmaktadır. Renk konusunda yapılan araştırmalarda renkle ilgili bulgulardan bazıları şöyledir:

- Sayfa üzerine konulan renkli kapakların, görsel stresi ve baş ağrısını azalttığı, aydınlatma ve metin özellikleri de dikkate alınarak- okul çağındaki çocukların \%25'inde okuma hızını arttırdığı tespit edilmiştir (Wilkins, 2001).

- Uyarıcı tasarıma ait mevcut standartlar ve talimatlarda, kırmızı, turuncu ve sarı renkleri tehlike, uyarı ve önlem sinyalleri olarak uygulanmaktadır. Katılımcılar üzerinde yapılan deneylerin sonuçları, yaralanma olasılığı, okunabilirlik, ürünün fark edilirliğine dayalı algılanan risk değişkenleri açısından renkle sunulan işaretlerin, etiketlerin, siyahbeyaza oranla çok daha okunaklı ve fark edilir olduğunu ortaya koymuştur (Braun, Mine, Silver, 1995).

Çalışma yeri rengi, çalışanların durumunu, tatminini, motivasyonunu ve performansını etkileyen bir çevresel faktördür. Sıcak renkleri insanları dışa odakladığı, çevreyle olan farkındalıklarını arttırdığı; soğuk renklerin ise içe döndürdüğünü, görsel ve zihinsel işlere odaklanmayı sağladığı görülür. Kırmızı saldırganlık, kızgınlık, gerilim, heyecan, mutluluk, dinamizm ile birlikte anılmakta, mavi, yeşil rahatlama, konfor, güvenlik, barış, huzurla ilişkili olmaktadır. Çalışma yerlerinde çevreyi izleyen öğrencilerin duygu ve düşünceleri üzerine yapılan anketlerde, mavi odada kırmızı odaya göre kendilerini daha sakin ve iyi hissettiklerini belirtmişlerdir. Çevresel ilişkiler açısından mavi sakinleştirici, kırmızı güdüleyici bir renk olmakla birlikte, çevre renklerinin işin niteliğine uygun seçilmesi gereklidir (Stone, 2003).

Renk, insanın fiziksel, zihinsel ve psikolojik özellikleri bağlamında önemli bir uyaran olarak, insan-nesne-çevre uyumuna katkı sağlamaktadır. Yarattığı psikolojik etkiler açısından, ürün tasarımı, mimarlık, grafik tasarım, makinelere ait gösterge ve kontroller, yazılım ergonomisi gibi farklı tasarım alanları kapsamında ele alınmış ve disiplinlerarası bir araştırma zemini hazırlanmıştır. Ergonomik bir faktör olarak dikkat, uyarı, motivasyon, verimlilik, iletişim, yaratıcılık gibi noktalardaki rolüyle, kazaların önlenmesi, konfor ve hijyen duygusunun yaratılması, çalışma koşullarının iyileştirilmesi, sosyal iletişim ortamlarının oluşturulmasına katkıları vurgulanmıştır.

\section{5. Çevresel Faktörler}

İnsancıl bir çalışma ortamının temeli, İnsana uygun ölçülerde tasarlanmış bir çevredir. Masa, oturma öğesi ve ayak dayanağı, birbirine uygun olmalıdır. Yanlış tasarlanmış bir çalışma çevresinin beraberinde getirdiği koşullar ve bunların olumsuz sonuçları, doğru çözümlenmiş tasarımlara ancak ortadan kalkabilir. 
Ofis mobilyası tasarımında antropometrik verilerden faydalanmak gerekir. İnsan vücudunun ölçüleri, organlarının uzunlukları, uzanabildikleri mesafe, ellerin ve ayakların hareket alanları bilinerek hareket edilmelidir.

Özellikle uzun saatler kullanımı gerektiren ofis mobilyası tasarımında "OWAS" ve "RULA" yöntemleri kullanılarak ergonomik ve konforlu mobilyalar meydana getirilir.

OWAS (Ovako Working Postures Analyzing System), çalışanın kas-iskelet sistemindeki yüklenmeyi ve sistemin neden olduğu kötü duruşları belirlemeye yarayan, gözleme dayalı bir çalışma duruşu analiz metodudur. OWAS metodu kullanılarak duruşlar sınıflandırılıp iş göreni rahatsız edecek unsurların ortadan kaldırılması için tasarıma yönelik sistematik iyileştirmeler ve geliştirmeler yapılabilmektedir (Akay vd., 2003). Bu yöntem çeşitli yazılımlar yardımıyla kullanılarak iş gören veya kullanıcının çalışma ya da herhangi bir nesneyi kullanım yerinde maruz kalabilecekleri rahatsızlıklar tespit edilebilmektedir. Rula yönteminde ise işin yapılabilmesi için gerekli güç ve tekrar hareketleri incelenerek üst uzuvlarda meydana gelen rahatsızlıkları inceleyen yöntemdir. Bu metot, üst uzuv (el-bilek-dirsek-alt kol-üst kol-omuz-boyun) rahatsızlıklarına neden olan kas-iskelet yüklenmelerine maruz kalan çalışanları değerlendirmek amacıyla puanlandırma sistemine dayalı olarak tasarlanmıştır (Kurban, Kaygın, Tankut-318).

\section{OFISLERDE KIŞISEL ALAN OLUŞTURMANIN ÖNEMI}

İnsanı çevreleyen dünyada birey rahatsız edici dış faktörlerden kendini uzak tutmaya yardımcı olan kişisel mekanını oluşturmaktadır. Hall, kişisel mekan kavramı içindeki mesafeyi; dokunma, duyma, koklama, görme gibi duyusal etkenlere bağlı bir iletişim aracı ve aynı zamanda bir koruyucu olarak görmektedir. Kişi kendi etrafında oluşturduğu "kişisel mekan" ını güvenlikli, odaklanabileceği, onu rahatsız eden dış etkenlerden uzak kalarak rahat çalışabileceği alan olarak hissetmek ister. Bu alanın oluşturulması iş verimliliğinin düşmemesi, çalışanın huzurlu olabilmesi ve motivasyonunun yükselmesi için büyük önem taşımaktadır. "Kişisel mekan" oluşturma, çalışanın fizyolojik sağlığını korumaya yönelik mekansal önlemlerin alınması ile birlikte, çevrenin insanlar üzerindeki psikolojik etkileri göz önünde bulundurularak yürütülmesi gereken bir konudur.

Cinsiyet ve yaş faktörleri "kişisel mekan" oluşturmada yönlendirici olabilmektedir. Kadınların erkeklere oranla sosyal çevreye daha kolay ve çabuk uyum sağladıkları bu bağlamda içinde rahat ve huzurlu oldukları alanlarını daha iyi oluşturabilmektedirler.

Kişinin mahrem alan oluşturma ihtiyacı içinde olması veya daha az mahremiyete intiyaç duymasında fiziksel çevrenin etkisi bulunmaktadır. "Kişisel alan" olgusu esas olarak kendilik bilgisinin ve iletişime ait paylaşılmış olan deneyimlerin dışavurumuyla ilgili bir süreçtir ve fiziksel çevre mahremiyetin akışını düzenlemektedir. Mekan ve yerlerin düzeni, bilgiyi yoğunlaştırmaya, yaymaya, saklamaya, ayırmaya ve yerini tayin etmeye neden olur. Fiziksel ortamlarda insanların kendilerini mahremiyet duygusu içinde hissedebilmelerini sağlayacak mimari unsurlar bulunabilmektedir. Bir mekan içerisindeki duvarlar, kapılar, bölücü elemanlar ya da görünürlüğü sınırlamaya elverişli herhangi bir eleman etkili olabilir.

Ofis ortamlarında değişik çalışma grupları bulunmaktadır ve bu grupların kendi oluşturdukları mahremiyeti düzenleme biçimleri bulunmaktadır. Örneğin; dışarıyla daha çok ilişki içinde olmayı gerektiren iş alanlarında ofis içindeki yerleşim alanları sosyal 
kontrol yönlerini vurgulayabilecekleri şekilde konumlandırılmıştır. Daha fazla konsantrasyon gerektirecek iş alanlarında ise çalışma ortamı daha çok dikkati dağıtacak unsurların olmadığı ve daha izole alanlarda konumlandırılmıştır. Mahremiyet, insanın başlıca ve değişmez gereksinimlerinden biri olması özelliği sayesinde evrensel bir olgu olmakla birlikte aynı zamanda fiziksel dünyayı ve sosyal ilişkileri düzenleme pratikleri açısından bakıldığında kültürel bir olgu olarak da tanımlanabilmektedir.

Kişisel mekan oluşturma, çevresel olduğu kadar sosyo-psikolojik bir kavramdır. Kişinin yaşantısının sosyal davranışlarla ilişkisi vardır ve bu durum onun davranış biçimine etki eder.

Mahremiyetle ilgili tanım ve yaklaşımlar değerlendirildiğinde, insanın fiziksel dünyayla olan ilişkilerinden çok sosyal dünyayla olan ilişkilerini düzenleyen bir kavram olduğu görülmektedir ve bu bağlamda incelendiğinde mahremiyet olgusu, kişisel mekan ve alan belirleme süreçleri arasında bir birleştirici durumundadır.

\section{DEĞERLENDIRME ve SONUÇ}

Ergonomi; insanın anatomik özelliklerini, antropometrik karakteristiklerini, fizyolojik kapasite ve toleranslarını dikkate alarak endüstriyel iş ortamındaki faktörlerinde etkisiyle oluşacak, organik ve psiko-sosyal stresler karşısında, sistem verimliliği ve insan-makine-çevre uyumu temel alınarak oluşturulmuş geniş kapsamlı bir araştırma ve çözüm üretme alanıdır.

Çalışanlara sağlık ve iş güvenliği açısından uygun ve rahat bir çalışma ortamı sağlandığı ölçüde iş gücünün verimi olumlu yönde etkilenecektir. İş yerinin aydınlatma, havalandırma, sıcaklık, soğukluk ve nem yönünden yeterli olması, kullanılan üretim sisteminin ergonomik açıdan uygunluğu fiziki açıdan ele alınması gereken en önemli unsurlardır.

Ergonomi iş verimliliğine etki eden önemli bir faktördür, fakat tek başına yeterli değildir. Ergonomi verimliliği artırıcı diğer tekniklerle (Sosyolojik, fizyolojik ve psikolojik) birlikte kullanıldığında olumlu sonuçlar verebilmektedir. Öncelikli hedef verimlilik için etkinliğin artııılması olmalıdır. İşletmede hedeflere ulaşma derecesi ne kadar yüksek olursa verimlilik ve istikrar o derece yükselecektir. Bu faktörlerin ergonomik prensipler doğrultusunda düzenlenmesiyle iş verimliliği artabilecek, çalışanın bedensel ve ruhsal sağlığı korunabilecektir.

İç mekan tasarımında aydınlatma düzeyinin ergonomik kurallar göz önünde bulundurularak ayarlanması, temiz ve sağlıklı hava akışının sağlanması, çalışma alanının gürültüden korunması ve gürültüye sebep olan araç-gereçlerin yeniden değerlendirilmesi, mobilyaların çalışanlar üzerindeki direkt etkisi göz önüne alınıp, daha az efor harcayacakları mobilyaların tasarlanmasıyla çalışanlar doğru düzenleme yapılmış bir sistem ile dış etkenlerden korunmuş olarak işlerini daha rahat ve huzurlu yapabileceklerdir. Doğru şekilde tasarlanmış bir ofis, çalışana insancıl bir ortam yaratarak psikolojik ve fizyolojik yönden sağlıklı kalması sağlayacaktır. Özellikle kapalı ve kalabalık ofis ortamlarında stres faktörü insana zarar verici ve psikolojik açıdan tahrip edici olabileceğinden bu konuda düşünülerek önlemler alınması gerekmektedir.

Ergonominin etki ettiği diğer bir unsur olan çalışanın fiziksel sağlığı da ofisin doğru şekilde tasarlanması aşaması ve verimliliği arttırma konularında göz önünde bulundurulmalıdır. Bu yönde yapılacak çalışmalarda en önemli faktör "insan" ve 
"insanın fiziksel sağlığının korunmasıdır. İnsanın fiziksel sağlığıyla birlikte psikolojisi de düşünülerek çözüm yöntemleri geliştirilmelidir.

Vücut ölçüleri ve oranları bireyden bireye farklılık gösterir. Ancak çalışma yeri düzenlemesinde çok özel bir durum gerektirmedikçe ortalama değerlerden yola çıkılır. Esas olarak dikkat edilmesi gereken noktalar kişinin gerektiğinde gün boyunca oturma pozisyonunda olabileceği, eğilerek veya ayakta durarak bazı işleri yerine getirmek zorunda kalabileceğidir. Dolayısıyla insanın yaptığı işi en az yorularak ve rahatsızlık hissetmeden, performansında ve motivasyonunda herhangi bir düşüş yaşamadan, işini gün boyu yapabilmesini sağlamaya yönelik nitelikte mobilyaların tasarlanabilmesidir. Yapılan çalışmada ergonomi biliminin insan sağlığı üzerindeki yadsınamaz etkisi üzerinde özellikle durulmuş ve tasarım faktörünün önemi vurgulanmıştır. Belli sınırılıkları olan insan bedeni üzerinde yapılan araştırmalar sonucunda yanlış duruş, uzun süreli oturma eylemi, ani eğilme ve kalkma gibi eylemler insan bedeni üzerinde uzun vadede çeşitli rahatsızlıkların oluşmasına neden olmaktadır. Geleceğin ofis mobilyaları tasarlanırken bugün yaşanan sorunlar, meydana gelen fiziksel ve psikolojik problemler ve sonucunda gelişen meslek hastalıklarının önüne geçilmesini sağlayacak unsurlar göz önünde bulundurulmalıdır. Tasarım, teknoloji ve insan ergonomik koşullarda bir araya gelmelidir.

\section{KAYNAKLAR}

Battaloğlu, C., "Çalışma Yerleri İçin Bir İş Bilimsel Denetim Listesi Geliştirilmesi ve Çalışma Yerlerinin Değerlendirilmesi” I. Ulusal Ergonomi Kongresi, Mp Yayınları, Ankara, 1989, s.372.

Braun, C., Mıne P.B., Sılver N.C.,"The İnfluence of Colour on Warning Label Perceptions", International Journal of Industrial Ergonomics , Cilt,15/3, 1995, s.179.

Çağlarca, S., "Renk ve Armoni Kuralları”, İnkılap Yay., 1993.

Doğan, N., "İnsan ve Masa- Oturma Öğesi İlişkileri”, Dım Design Instıtut GmbhMünchen, 1996.

Duran, Sağocak., M.,"Ergonomik Tasarımda Renk", Trakya Univ J Sci, Cilt, 6(1), 2005, s. 77-83.

Durgun, B., Ergonomik Tasarımda Antropometrik Modelleme: Uyum, Konfor ve Estetik, 16. Ulusal Ergonomi Kongresi "Yaşam Kalitesi İçin Ergonomi" Bildiriler Kitabı, Çorum, Basım, 2013, s. 151-158.

Göregenli, M., "Çevre Psikolojisi, İnsan Mekan İlişkisi", İstanbul Bilgi Üniversitesi Yay., 2005.

Güler, Ç., "Ergonomiye Giriş”, 1.Baskı, Ankara, 1997.

Güney, S., "İnsanın Psikolojik Yapısı ve Ergonomi”, 1. Sistem Mühendisliği ve Savunma Uygulamaları Sempozyumu Bildiriler Kitabı, Ankara, 1995.

Kahraman, M. F., Türkiye`de Antropometrik Verilere Göre Ofiste Ergonomik İşyeri Tasarımı, Çalışma ve Sosyal Güvenlik Bakanlığı İş Sağlığı ve Güvenliği Genel Müdürlüğü, İ̧ Sağlığı ve Güvenliği Uzmanlık Tezi / Araştırma, Ankara, 2013. 
Kıraç, Y., "Büro Yönetiminde Ergonomi ve Ergonominin Verimliliğe Etkisi", T.C. Gazi Üniversitesi, Büro Yönetimi ABD, Yüksek Lisans Tezi, Ankara, 2005.

Harris, C.M., "Handbook of Noise and Acoustical Measurement", Mc-Graw Hill, Bölüm 41, 1991.

Kurban, H, Kaygın, B, Tankut, A,N,. "Mobilya Tasarımında Antropometrik Ölçü ve Ergonomik Analizlerin Kullanımı" İnönü Üniversitesi Sanat ve Tasarım Dergisi, İnönü University Journal of Art and Design, 2016, s. 1-101.

Kaya, Ö, Özok, A,F., "Tasarımda Antropometrinin Önemi”, Mühendislik Bilimleri ve Tasarım Dergisi, 2017, s. 316.

Stone, N.J., "Environmental View and Color for a Simulated Telemarketing Task", 19 Journal of Environmental Psychology, Cilt, 23/ 1, 2003, s. 63-78.

Su, A, B., "Ergonomi", Ankara; Atılım Üniversitesi Mühendislik Fak. Yay., 2001.

Wılkıns, A., "Coloured Overlays and Their Benefit for Reading", Journal of Research İn Reading, Cilt, 24/1, 2001, s. 41-46. 